\title{
INOVASI PEMBELAJARAN INTEGRATIF PAI BERBASIS OUTBOUND SAINS DI MADRASAH IBTIDAIYAH
}

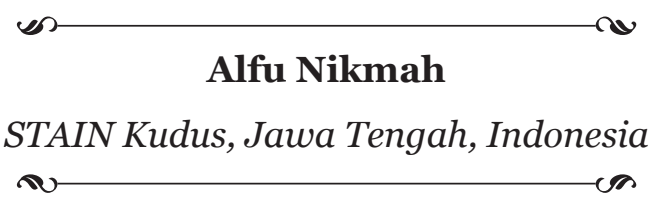

\begin{abstract}
INNOVATION OF ISLAMIC EDUCATION INTEGRATIVE LEARNING BASED ON OUTBOUND SCIENCE IN ISLAMIC ELEMENTARY SCHOOL: Understanding of science materials will be very significant when it is associated with the applicative environment in everyday life and refers to the 2013 curriculum which applies integrative learning methods, starts with the basic level, namely the primary school. This article discussed the innovation of learning and integrative learning science through outbound activities and PAI learning. This article was conducted by using the method of literature review of several sources. The Results from the research literature showed that integrative learning of science and PAI is an innovation study in Madrasah which can increase students' motivation. Learning science can be implemented on the outside or outbound learning that now it has been developed in the educational process. Outbound science implemented the learning in the field directly. it enables students to learn and interact directly with the surrounding or environment. The science studies the natural phenomena that is is related to PAI learning which learn the creation of nature against the creator. Key words: integrative learning, Out-Bound Science, innovation learning in Madrasah
\end{abstract}

\section{A. Pendahuluan}

Perkembangan ilmu pengetahuan, teknologi dan seni (IPTEKS) yang pesat sekarang ini berakibat pada perubahan-perubahan di berbagai bidang kehidupan. Perubahan ini sangat berpengaruh dengan pendidikan. Pendidikan terus berkembang sesuai dengan kemajuan IPTEKS, begitu juga kemajuan IPTEKS sangat berpengaruh dengan perkembangan pendidikan. Mulyasa (2008: 9) mengemukakan bahwa pendidikan harus dapat memenuhi tuntutan dan kebutuhan masyarakat, terutama dalam kaitannya dengan 


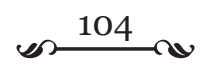

permasalahan- permasalahan perkembangan IPTEKS.

Beberapa fakta yang dapat diketahui, saat berada di sekolah dalam proses belajar mengajar siswa kurang didorong untuk mengembangkan kemampuan berpikir.Proses pembelajaran di dalam kelas didominasi oleh kegiatan belajar yang sifatnya kognitif saja, yang sifatnya menghafal dan mengingat berbagai materi saja. Siswa tidak dituntut untuk memahami dan menghubungkan informasi dan menghubungkannya dengan kehidupan sehari-hari mereka.Dengan demikian, pembelajaran dengan menerapkan pendekatan menghafal tersebut kurang mendorong siswa untuk dapat mengembangkan kemampuan berpikir.

Aplikasinya dalam pembelajaran sains diantaraya siswa terkesan menghafalkan materi yang diberikan oleh guru. Banyaknya materi yang diberikan oleh guru membuat siswa tidak dapat memahami informasi secara tepat dengan tanpa menghubungkan informasi dalam kehidupan seharihari. Tujuan akhir para siswa hanyalah mendapatkan scor yang sempurna tanpa mendapatkan peasan atau nilai-nilai yang terkandung dalam materi.

Sehingga pembelajaran yang dilakukan masih belum bermakna. Sebagaimana diungkapkan Abdurrahman (2007: 100) bahwa selama mengikuti pembelajaran di sekolah, siswa jarang bersentuhan dengan pendidikan nilai yang berorientasi pada pembentukanwatak dan kepribadian. Hal tersebut mengakibatkan pembelajaran kurang bermakna dan juga mengakibatkan siswa kurang termotivasi untuk mempelajari sains yang ditunjukkan dengansikap bosan mengikuti proses pembelajaran sehingga sains kurang berkesan dalam benak mereka (Martin, et. al., 2005: 6). Dengan demikian, perlu suatu pendekatan pembelajaran yang sesuai dengan tahap perkembangan intelektual siswa dan dapat memberikan makna bagi siswa untuk dapat menjadi manusia seutuhnya.

Kurikulum Madrasah Ibtidaiyah Tahun 2013 menggunakan pendekatan pembelajaran tematik integratif mulai dari kelas I sampai kelas VI.Pembelajaran tematik integratif merupakan pendekatan pembelajaran yang mengintegrasikan berbagai kompetensi dari berbagai mata pelajaran ke dalam berbagai tema.Tema adalah pokok pikiran atau gagasan pokok yang menjadi pokok pembicaraan (Poerwadarminta, 1983).

Pendekatan pembelajaran ynag mengintegrasikan berbagai kompetensi ini diharapkan dapat memperdalam pemahaman siswa dalam mempelajari suatu pelajaran tertentu yang saling berkaitan dengan pelajaran yang lain. 


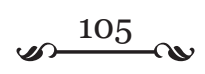

Proses pengintegrasisn pelajaran sains yang selama ini menjadi momok bagi para pelajar akan lebih bermakna saat proses pembelajaran dilakukan di luar kelas dengan mengenalkan langsung materi yang sedang dipelajari. Sebagaimana pelajaran sains yang diinetgrasikan dengan pelajaran PAI. Penbelajaran PAI di sekolah yang berlaku selama ini di susun oleh Kementerian Agama dan Kementerian Pendidikan Nasional dengan organisasi Corelated Subject matter Curricullum yang mengaitkan beberapa mata pelajaran yang terpisah seperti Al-Quran Hadith , Aqidah Akhlak, Fiqih ibadah, Muamalah dan Sejarah Islam. Pada abad informasi ini model pengembangan kurikulum PAI perlu ada pembaharuan dengan model integrasi, artinya semua ilmu pengetahuan terkait dipadukan ke dalam mata pelajaran PAI di sekolah. Bagaimana pengetahuan kealaman (IPA/IPS) dapat di integrasikan ke dalam materi PAI di sekolah-sekolah.

Pembelajaran integratif antara IPA atau sains dan PAI menjadi suatu inovasi pembelajaran yang dapat meningkatkan motivasi belajar siswa. Pembelajaran sains yang diimplemantasikan dengan pembelajaran di luar atau outbound sekarang banyak dikembangkan dalam proses pendidikan. Out-bound sains yang menekankan pembelajaran secara langsung di lapangan membuat siswa dapat belajar dan berinteraksi secara langsung dengan sekitar atau lingkungan. Kandungan alam yang banyak dipelajari ini sangat bersentuhan secara langsung dengan pembelajaran PAI yang mengkaitkan penciptaan femonema alam terhadap sang pencipta.

\section{B. Pembahasan}

\section{Pembelajaran Integratif}

Belajar adalah proses perubahan di dalam kepribadian berupa kecakapan, sikap, kebiasaan, dan kepandaian. Perubahan ini bersifat menetap dalam tingkah laku yang terjadi sebagai hasil dari latihan atau pengalaman. Pembelajaran adalah suatu proses interaksi antar anak dengan anak, anak dengan sumber belajar, dan anak dengan guru/ pendidik (Daniel L. Schacter, et al., 2011:264).

Proses belajar mengajar akan senantiasa merupakan proses kegiatan interaksi antara dua unsur manusiawi, yakni siswa sebagai pihak yang belajar dan guru sebagai pihak yang mengajar, dengan siswa dengan subjek pokoknya (Sardiman, 2007:14).Dalam interaksi belajar mengajar, seorang guru sebagai pengajar akan berusaha secara maksimal dengan 


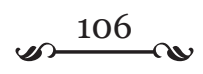

menggunakan berbagai ketrampilan dan kemampuaannya agar anak didik dapat mencapai tujuan yang diharapkan. Oleh karena itu, menurut Soetomo "guru harus dapat menciptakan situasi dimana anak dapat belajar, sebabsebenarnya proses belajar mengajar itu belum dapat belajar dan belum mengalami perubahan tingkah laku" (Soetomo,1993:10), karena perubahan tingkah laku sendiri merupakan hasil belajar.

Sedangkan menurut Nasution, pembelajaran adalah suatu aktifitas mengorganisasi atau mengatur lingkungan sebaik-baiknya dan menghubungkannnya dengan peserta didik sehingga terjadi proses belajar (Nasution, 1995:4)sehingga pembelajaran menekankan pada aktivitas peserta didik, sedangkan pengajaran menekankan pada aktifitas pendidik. Dengan pembelajarn diharapkan dapat mencapai tujuan pembelajaran yakni peserta didik diharapkan bisa berubahdengan apasaja yang dia dapatkan. Belajar mempunyai maksud agar sesuatu yang belum diketahui akan di dapat di dalamnya. Tujuan pengajaran sebagaimana diungkapkan oleh Oemar Hamalik, 2009: 109 "suatu deskripsi mengenai tingkah laku yanga diharapkan tercapai oleh siswa setelah berlangsung pengajaran”. Jadi tujuan pembelajaran adalah harapan perubahan yang dicapai oleh peserta didik dari adanya proses pembelajaran.

Dalam pembelajaran, pendidik diharapkan dapat menggunakan cara yang paling tepat dalam proses belajar mengajar. Penddiik harus bisa menerapkan metode yang tepat tbagi anak didiknya. Metode merupakan suatu cara yang dipergunakan untuk mencapai tujuan yang telah ditentukan (Fathurrahman, 2007:15). Sedangkan metode mengajar ialah cara yang dipergunakan guru dalam mengadakan hubungan dengan siswa pada saat berlangsungnya pengajaran (Tarigan, 1990 :41). Sedangkan metode pembelajaran adalah cara-cara atau teknik penyajian bahan pelajaran yang akan digunakan oleh guru pada saat menyajiakan bahan pelajaran baik secara individual atau secara kelompok(sabri, 2005 :52)

Menurut Nana Sudjana, (2004 :77-89) menyebutkan metode pengajaran diantaranya mencakup metode Ceramah, metode Tanya Jawab, metode Diskusi, Metode Tugas Belajar dan Resitasi, Metode kerja kelompok, Metode Demonstrasi dan Eksperimen, Metode Sosiodrama (Role-Playing), Problem Solving, Metode Sistem Regu (Team Teaching), Metode Latihan (Drill), Metode Karya Wisata (Field-Trip), Metode Resource Person (Manusia Sember), Metode Survey Masyarakat, Metode 


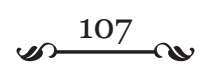

Simulasi.

Metode Pembelajaran yang berkembang saat ini banyak digunakan oleh para pendidik diantaranya field trip atau sejenis out-bound. Metode ini disesuaikan dengan kebutuhan peserta didik yang dapat berinteraksi dengan lingkungan. Dalam pembelajaran melalui outbound di luar dapat mengembangkan polapikir siswa dalam mempelajari materi dengan mengkaitkan materi dengan materi yang lain yang dikenal dengan pembelajaran integratif.

Pembelajaran integratif lebih menekankan pada keterlibatan siswa dalam proses belajar secara aktif dalam proses pembelajaran, sehingga siswa dapat memperoleh pengalaman pengalaman langsung siswa akan memahami konsep-konsep yang mereka pelajari dan menghubungkannya dengan konsep lain yang telah dipahaminya.

Selain dimotori oleh teori pembelajaran Gestalt, pembelajaran ini dimotori pula oleh Piaget yang menekankan bahwa pembelajaran haruslah bermakna dan berorientasi pada kebutuhan dan perkembangan anak. Piaget (1950) menyatakan bahwa setiap anak memiliki cara tersendiri dalam menginterpretasikan dan beradaptasi dengan lingkungannya (teori perkembangan kognitif). Menurutnya, setiap anak memiliki struktur kognitif yang disebut schemata yaitu sistem konsep yang ada dalam pikiran sebagai langsung dan terlatih untuk dapat menemukan sendiri berbagai pengetahuan yang dipelajarinya.Melalui hasil pemahaman terhadap objek yang ada dalam lingkungannya. Pemahaman terhadap objek tersebut berlangsung melalui proses asimilasi (menghubungkan objek dengan konsep yang sudah ada dalam pikiran) dan akomodasi (proses memanfaatkan konsep-konsep dalam pikiran untuk menafsirkan objek). Jika kedua proses tersebut berlangsung terus-menerus, akan membuat pengetahuan lama dan pengetahuan baru menjadi seimbang, sehingga secara bertahap anak dapat membangun pengetahuan melalui interaksi diri anak dengan lingkungannya.

Anak usia Madrasah Ibtidaiyah berada pada tahapan operasional kongkret dan perilaku belajarnya ditandai dengan beberapa hal seperti ; (1) mulai memandang dunia secara objektif, bergeser dari satu aspek ke aspek lain secara reflektif dan serentak, (2) mulai berpikir secara operasional, (3) berpikir operasional untuk mengklasifikasikan bendabenda, (4) membentuk dan mempergunakan keterhubungan aturan- 


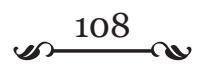

aturan, prinsip ilmiah sederhana dan mempergunakan hubungan sebab akibat, (5) memahami konsep substansi, volume, panjang, lebar, luas, dan berat. Ciri belajar anak usia Madrasah Ibtidaiyah adalah, (1) kongkret (dapat dilihat, didengar, dibau, dikecap, diraba, dan diotak-atik), (2) integratif (segala sesuatu dipandang sebagai satu keutuhan), (3) hierarkis (urut, logis, keterkaitan antar materi, cakupan keluasan dan kedalaman materi) (Musfiroh, 2011:11).

\section{IntegrasiPAI dengan Sains}

Pembahasan tentang Pendidikan Agama Islam seringkali dikaitkan dengan Pendidikan Islam. Sebagian orang memahami bahwa antara Pendidikan Islam dan Pendidikan Agama Islam memiliki arti dan makna yang sama. Bahkan pendidikan Islam lebih banyak dipahami sebagai mata pelajaran di sekolah, yang secara formal diberikan kepada seluruh siswa yang beragama Islam. Pendidikan Islam memiliki makna berbeda dengan pendidikan lain.

Menurut Rohmad, 2015:19 mengatakan bahwa Pendidikan Islam adalah nama kegiatan atau usaha-usaha dalam mengajarkan Agama Islam. Secara formal, Pendidikan Agama Islam dipahami sebagai mata pelajaran yang diberikan kepada siswa di setiap satuan pendidikan. Dalam struktur kurikulum di sekolah, mata pelajaran Pendidikan Agama Islam memiliki posisi setara dengan mata pelajaran lain, seperti IPS, IPA, Bahasa Indonesia, serta mata pelajaran lain. Sementara itu, Nurhayati Djamas dalam Rohmad (2015: 19)memahami bahwa Pendidikan Agama Islam di sekolah merupakan salah satu bentuk pendidikan Islam.Pemahaman ini senada dengan konsep Muhaimin yang menyatakan pendidikan agama Islam merupakan bagian Pendidikan Islam.

Merujuk pada beberapa pendapat di atas, penulis memahami bahwa Pendidikan Agama Islam adalah kegiatan dan usaha untuk mengajarkan materi Agama Islam melalui proses pendidikan yang betujuan untuk mewujudkan tujuan Pendidikan. Keberadaan Pendidikan Agama Islam di sekolah merupakan bentuk implementasi kebijakan pendidikan yang secara legal formal tertuang dalam Undang-Undang Nomor 20 tahun 2003 tentangSistem Pendidikan Nasional (Sisdiknas), yang kemudian telah dilengkapi dengan turunan peraturan tentang pelaksanaan PAI di sekolah. Dalam kurikulum nasional, Pendidikan Agama Islam merupakan salah 


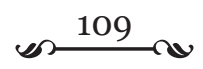

satu dari tiga mata pelajaran yang harus dimasukkan dalam kurikulum setiap lembaga pendidikan formal di Indonesia(Rohmad,2015:20).

Pusat Kurikulum Depdiknas mengemukakan bahwa Pendidikan Agama Islam di Indonesia bertujuan untuk menumbuhkan dan meningkatkan keimanan, peserta didik melalui pemberian dan pemupukan pengetahuan, penghayatan, pengamalan serta pengalaman peserta didik tentang agama Islam sehingga menjadi manusia muslim yang terus berkembang dalam hal keimanan, ketakwaan kepada Allah SWT, serta berakhlak mulia dalam kehidupan pribadi, bermasyarakat, berbangsa dan bernegara.

Berangkat dari pemahaman makna dan tugas berat yang diemban oleh PAI disekolah maka pembelajaran pendidikan agama Islam diarahkan dapat membentuk peserta didik mempunyai kepribadian yang memiliki integritas diniyah (tafakkuh fi al din) dan loyalitas nasional. Suatu kepribadian yang utuh ini tidak saja mencakup ketaatan beragama, tetapi lebih dari itu memiliki kesanggupan untuk menjaga dan mengawal Negara Kesatuan Republik Indonesia.Untuk mencapai tujuan yang demikian mulia itu rasanya tidak mungki terwujud apabila kurikulum atau GBPP PAI menggunakan model organisasi Corelated Subyek Curriculum, Kompetensi dasarnya hanya rajin berdzikir dan berdoa, gemar membaca $\mathrm{Al}$-Quran, sholat lima waktu dan terbiasa berakhlak mulia(Rohmad,2015:22)

Pembelajaran PAI di sekolah yang berlaku selama ini disusun oleh Kementerian Agama dan Kementerian Pendidikan Nasional dengan organisasi Corelated Subject matter Curricullum yang mengaitkan beberapa mata pelajaran yang terpisah seperti Al-Quran Hadith, Aqidah Akhlak, Fiqih ibadah, Muamalah dan Sejarah Islam. Pada era sekarang ini model pengembangan kurikulum PAI perlu ada pembaharuan dengan model integrasi, artinya semua ilmu pengetahuan terkait dipadukan ke dalam mata pelajaran PAI di sekolah.Bagaimana pengetahuan kealaman (IPA/IPS) dapat di integrasikan ke dalam materi PAI di sekolah-sekolah. Sekat-sekat dikotomis agama dan umum karenanya perlu ditinggalkan.

Oleh karena itu, penyusunan buku teks materi PAI harus disusun lebih komprehensif dan holistik. Kemudian para Guru PAI ke depan juga dituntut memiliki basic pengetahuan yang lebih luas. Mereka harus melek ilmu kealaman dan ilmu sosial humaniora disamping menguasai ilmu 


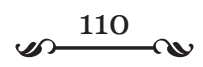

keislaman yang menjadi kompetensinya sehingga para guru PAI dapat mengintegrasikan materi keagaaman dengan materi yang lain. Begitupun sebaliknya, para guru berbasis sains maupun humaniora juga harus membekali diri dengan pendidikan keagamaan. Integrasi PAI dengan mata pelajaran yang lain harus diimplemenatasikan mengingat era globalisasi yang semakin menggerus nilai-nilai maupun kepribadian anak negeri.

Efek dari globalisasi yang melanda dengan adanya serbuan informasi era Cyber dan Digital dalam dunia maya ini mempunyai pengaruh yang sangat besar dan luas dalam membentuk opini publik di masyarakat luas. Hal ini dikarenakan mudahnyamengaksesinformasi secara cepat tanpa memerlukan waktu yang lama. Oleh karena itu diperlukan konsep-konsep baru yang dapat mencerahkan, yang dapat mengolah dan meramu kembali silaby, kurikulum, metode, pendekatan, fisolofi pendidikan agama Islam yang dapat mengantarkan para peserta didik dan masyarakat luas untuk tetap dapat berfikir jernih, santun, etis, penuh pertimbangan yang rasional, logis dan dapat mengantarkan mereka untuk bertindak "act locally think globally" tanpa mengorbankan salah satunya.

Pendidikan agama Islam diberikan dengan mengikuti tuntunan bahwa agama diajarkan kepada manusia dengan visi untuk mewujudkan manusia yang bertaqwa kepada Allah SWT dan berakhlak mulia, serta bertujuan untuk menghasilkan manusia yang jujur, adil, berbudi pekerti, etis dan saling menghargai, disiplin, harmonis dan produktif, baik personal maupun sosial. Tuntutan visi ini mendorong dikembangkannya standar kompetensi sesuai dengan jenjang persekolahan yang secara nasional ditandai dengan ciri-ciri a) Lebih menitik beratkan pencapaian kompetensi secara utuh selain penguasaan materi, b) Mengakomodasikan keragaman kebutuhan dan sumber daya pendidikan yang tersedia, c) Memberikan kebebasan yang lebih luas kepada pendidik di lapangan untuk mengembangkan strategi dan program pembelajaran sesuai dengan kebutuhan dan ketersediaan sumberdaya pendidikan(Nasaruddin, 2007:62)

Tujuan Pendidikan Agama Islam di Sekolah Dasar (SD) dan Madrasah Ibtidaiyah (MI) adalah 1)Menumbuhkembangkan akidah melalui pemberian, pemupukan, dan pengembangan pengetahuan, penghayatan, pengamalan, pembiasaan, serta pengalaman peserta didik tentang agama Islam sehingga menjadi manusia muslim yang 
terus berkembang keimanan dan ketaqwaannya kepada Allah SWT, 2) Mewujudkan manusia Indonesia yang taat beragama dan berakhlaq mualia yaitu manusia yang berpengetahuan, rajin beribadah, cerdas, produktif, jujur, adil, etis, berdisiplin, bertoleransi (tasamuh), menjaga keharmonisan secara personal dan sosial serta mengembangkan budaya agama dalam komunitas sekolah (Nazarudin, 2007:63)

Sedangkan ruang lingkup Pendidikan Agama Islam meliputi beberapa aspek-aspek diantaranya a) Alqur'an Hadits, b) Aqidah, c) Akhlaq, d) Fikih, e) Tarikh dan Kebudayaan Islam. Pendidikan Agama Islam menekankan keseimbangan, keselarasan, dan keserasian antara hubungan manusia dengan Allah SWT, hubungan manusia dengan sesama manusia, hubungan manusia dengan diri sendiri, dan hubungan manusia dengan alam sekitarnya.

Mengintegrasikan nilai-nilai Islam dalam pembelajaran tematik memungkinkan siswa dapat mengintegrasikan ide-ide intern dalam suatu bidang studi.Siswa memungkinkan dapat mengkaji, mengkonseptualisasi, memperbaiki, serta mengasimilasi, memperbaiki ide-ide dalam memecahkan masalah, terutama dalam bingkai moralitas dan spiritualitas Islam.Dengan adanya hubungan atau kaitan antara gagasan di dalam satu bidang studi, siswa-siswi mempunyai gambaran yang lebih komprehensif dari beberapa aspek tertentuyang mereka pelajari secara mendalam.

Menurut (Abdul Kadir, 2015:55),sebelum guru melaksanakan pembelajaran tematik dengan mengintegrasikan nilai-nilai Islam, sebaiknya guru melakukan langkah-langkah pengembangan Integrasi Nilai-nilai Islam dengan berbagai mata pelajaransebagai berikaut:

\section{a. Melakukan Analisis Kompetensi}

Integrasi nilai-nilai Islam dengan berbagai mata pelajaran dapat dilakukan dengan melakukan analisis kompetensi dengan mengidentifikasibentuk-bentuksikap.MenurutRalphW.Tyler(2005) identifikasi sikap dapat menggunakan matriks yang menghadapkan pokok-pokok bahasan dalam suatu mata pelajaran dengan sikap. Matriks yang digunakan sebgai alat untuk menjabarkan sikap-sikap bernilai Islami dapat menggunakan model yang dikembangkan oleh Nasar (2006) dengan sub tema Diri Sendiri sebagaimana tabel dibawah ini: 


\begin{tabular}{|c|c|c|c|c|c|}
\hline $\begin{array}{c}\text { Mata } \\
\text { Pelajaran }\end{array}$ & $\begin{array}{l}\text { Kompetensi } \\
\text { Dasar }\end{array}$ & $\begin{array}{c}\text { yang harus } \\
\text { diketahui } \\
\text { (Pengetahuan) }\end{array}$ & $\begin{array}{c}\text { yang bisa } \\
\text { dibuat } \\
\text { (Ketrampilan) }\end{array}$ & $\begin{array}{c}\text { yang bisa } \\
\text { diperagakan }\end{array}$ & $\begin{array}{c}\text { yang bisa } \\
\text { diterapkan } \\
\text { Siswa(Sikap) }\end{array}$ \\
\hline Agama & $\begin{array}{l}\text { Menyebutkan } \\
\text { pengertian } \\
\text { bersuci }\end{array}$ & $\begin{array}{l}\text { - Pengertian suci } \\
\text { - Macam macam } \\
\text { bersuci } \\
\text { - Macam-macam } \\
\text { air yang } \\
\text { mensucikan }\end{array}$ & - & $\begin{array}{l}\text { Memperagakan } \\
\text { wudlu dan } \\
\text { tayammum }\end{array}$ & $\begin{array}{l}\text { Melaksanakan } \\
\text { wudlu dengan } \\
\text { santun }\end{array}$ \\
\hline Matematika & $\begin{array}{l}\text { Membilang } \\
\text { banyak benda }\end{array}$ & - bilangan & $\begin{array}{l}\text { Menghitung } \\
\text { benda sekitar }\end{array}$ & $\begin{array}{l}\text { Berbaris dan } \\
\text { berhitung }\end{array}$ & $\begin{array}{l}\text { Tertib dalam } \\
\text { berhitung }\end{array}$ \\
\hline IPA & $\begin{array}{l}\text { Mengenal } \\
\text { bagian } \\
\text { tubuh dan } \\
\text { kegunaannya } \\
\text { serta cara } \\
\text { perawatannya }\end{array}$ & $\begin{array}{l}\text { Anggota tubuh dan } \\
\text { fungsinya macam- } \\
\text { macam alat indra }\end{array}$ & $\begin{array}{l}\text { Menggambar } \\
\text { tangan }\end{array}$ & $\begin{array}{l}\text { Menunjukkan } \\
\text { bagian-bagian } \\
\text { tubuh }\end{array}$ & $\begin{array}{l}\text { Menghargai } \\
\text { anggota } \\
\text { tubuh sebagai } \\
\text { ciptaan Allah }\end{array}$ \\
\hline $\begin{array}{l}\text { Bahasa } \\
\text { Indonesia }\end{array}$ & $\begin{array}{l}\text { Mengulang } \\
\text { deskripsi } \\
\text { tentang benda- } \\
\text { benda sekitar }\end{array}$ & $\begin{array}{l}\text { Membaca, } \\
\text { mendengarkan, } \\
\text { menulis, dan } \\
\text { menjelaskan } \\
\text { tentang benda- } \\
\text { benda di sekitar }\end{array}$ & $\begin{array}{l}\text { Membuat } \\
\text { karangan }\end{array}$ & & \\
\hline IPS & $\begin{array}{l}\text { Memnceritakan } \\
\text { kenmbali } \\
\text { peristiwa } \\
\text { penting yang } \\
\text { dialami sendiri } \\
\text { di lingkungan } \\
\text { keluarga }\end{array}$ & $\begin{array}{l}\text { Pekerjaan } \\
\text { orang tua dan } \\
\text { keluargaku }\end{array}$ & & & $\begin{array}{l}\text { Bangga } \\
\text { terhadap } \\
\text { pekerjaan } \\
\text { keluarga dan } \\
\text { orang tua }\end{array}$ \\
\hline PPKN & $\begin{array}{l}\text { Menjelaskan } \\
\text { hak anak } \\
\text { untuk bermain, } \\
\text { belajar dengan } \\
\text { gembira dan } \\
\text { didengar } \\
\text { pendapatnya }\end{array}$ & $\begin{array}{l}\text { Hak anak untuk } \\
\text { bermain,belajar } \\
\text { dan didengar } \\
\text { pendapatnya }\end{array}$ & & $\begin{array}{l}\text { MElakukan } \\
\text { refleksi hak-hak } \\
\text { yang diperoleh } \\
\text { anak }\end{array}$ & $\begin{array}{l}\text { Bersyukur } \\
\text { kepada orang } \\
\text { tua karena } \\
\text { hak-hak yang } \\
\text { diperoleh anak. }\end{array}$ \\
\hline
\end{tabular}

\section{b. Mengembangkan Pengalaman Belajar Sebagai Sarana Menanamkan Sikap Islami}

Pengalaman belajar bukan muatan mata pelajaran atau materi pelajaran.Pengalaman belajar sebagaimana dijelaskan Tyler (2005:74) adalah interaksi antara pelajar dan kondisi eksternal di lingkungan dimana siswa dapat bereaksi.Pengalaman belajar 


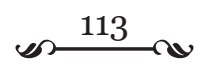

sangat bermanfaat untuk mencapai tujuan pembelajaran, seperti mengembangkan ketrampilan berfikir, memperoleh informasi, dan membantu dalam mengembangkan sikap sosial.Misalnya, untuk menanamkan sikap bersyukur kepada orangtua karena hak-hak yang diperoleh anak-anak, guru dapat memilih pengalaman belajar refleksi untuk menyadari bimbingan orang tua dalam pendidikan, atau membelikan permainan pada anak agar anak menikmati masa bahagia.

\section{Outbound Sains}

Pembelajaran sains dengan memanfaatkan lingkungan dapat dilakukan dengan cara membawa lingkungan ke dalam kelas, seperti: menghadirkan pemateri untuk menyampaikan materi di dalam kelas(Trinova,2010:179). Selanjutnya, agar penggunaan lingkungan sebagai sumber belajar berjalan efektif, maka perlu dilakukan perencanaan, pelaksanaan dan evaluasi, serta tindak lanjutnya. Di sampingitu pemanfaatan lingkungan dapat ditempuh dengan cara melakukan kegiatan dengan membawa siswa ke lingkungan, seperti survey, karyawisata, berkemah, praktek lapangan, dan sebagainya.

Pembelajaran outbound sains memungkinkan siswa mengalami langsung konsep yang dipelajari serta mengembangkan penalaran logis dan mengajarkan siswa untuk menguasai nilai-nilaispiritual, emosional dan intelektual secara optimal.Hal itu dikarenakan materi pembelajaran dapat dirangkum menjadi kegiatan yang dekat dengan pengalaman siswa dalam kesehariannya sehingga menjadi bermakna bagi kehidupan.

Outbound adalah suatu program pembelajaran di alam terbuka yang berdasarkan pada prinsip experientiallearning (belajar melalui pengalaman langsung) yang disajikan dalam bentukpermainan, simulasi, diskusi dan petualangan sebagai media penyampaian materi. Artinya dalam program out-bound tersebut siswa secara aktif dilibatkan dalam seluruh kegiatan yang dilakukan.Kegiatan belajar yang langsung terlibat pada aktivitas (learning by doing) siswa akan segera mendapat umpan balik tentang dampak dari kegiatan yang dilakukan, sehingga dapat dimanfaatkan sebagai bahan pengembangan diri setiap siswa dimasa mendatang. Hal tersebutjuga dapat diartikan bahwa proses belajar dari pengalaman (experiental learning) dengan menggunakan seluruh panca 


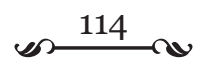

indera (global learning) yang nampaknyarumit, memiliki kekuatan karenasituasinya "memaksa" siswa memberikan respon spontan yang melibatkan fisik, emosi, dan kecerdasan sehingga secara langsung mereka dapat lebih memahami diri sendiri dan orang lain serta lingkungannya. Selain itu, Selain itu, outbound juga dikenal dengan sebutan media outbound activities.

Menurut Gordon dan Browne(Moeslichatoen, 1999: 57-58) terdapat beberapa aspek yang perlu diperhatikandalam memilih bahan dan peralatanoutbound sains.Beberapa aspek tersebut diantaranya; a) Memilih bahan untuk kegiatanbermain yang mengundang perhatiansemua siswa, yakni bahanbahanyang dapat memuaskankebutuhan, menarik minat, dan menyentuh perasaan mereka, b) Memilih bahan yang multi guna yang dapat memenuhi bemacam tujuan pengembangan seluruh aspek perkembangan siswa, c) Memilih bahan yang dapat memperluas kesempatan siswa untuk menggunakannya dengan bermacam cara, d) Memilih bahan yang mencerminkan karakteristik tingkat usia kelompok siswa, e) Memilih bahan harus sesuai dengan filsafat dan napas kurikulum yang dianut, f) Memilih bahan yang mencerminkan kualitas rancangan dan keterampilan kerja, g) Memilih bahan dan peralatan yang tahan lama, h) Memilih bahan-bahan yang dapat dipergunakan secara fleksibel dan serba guna, i) Memilih bahan yang mudah dirawat dan diperbaiki, j) Memilih bahan yang mencerminkan peningkatan budaya kelompok, k) Memilih bahan yang tidak membedakan jenis kelamin dan meniru- niru.

Pembelajaran dengan outbound ini yang berdasarkan pengalaman ini menyediakan suatu alternatif pengalaman belajar bagi siswa yang lebih luas daripada pendekatan yang diarahkan oleh guru kelas di MI. Strategi ini menyediakan banyak kesempatan belajar secara aktif, personalisasi dan kegiatan-kegiatan belajar yang lainnya bagi para siswa untuk semua tingkat usia. Pembelajaran ini guru dapat menginternalisasikan dimensi spiritual ke dalam kegiatan belajar siswa, agar apa yang siswa pelajari dapat mendekatkan siswa kepada Allah SWT (Sang Pencipta).

Outbound merupakan salah satu metode pembelajaran yang dapat digunakanoleh guru di MI melalui interaksi antar siswa dan alam melalui kegiatan simulasi di alam terbuka. Hal tersebut diyakini dapat memberikan suasana yang kondusif untuk membentuk sikap, cara berfikir serta persepsi yang kreatif dan positif dari setiap siswa. Selain itu, melaluisimulasi 


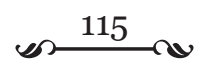

outdoor activities, siswa juga akan mampu mengembangkan potensi diri, baik secara individu (personaldevelopment) maupun dalam kelompok (team development).

Tujuan outbound menurut Adrianus dan Yufiarti adalah; a) Untukmengidentifikasi kekuatan dankelemahan diri siswa, b) Berekspresi sesuai dengan caranyasendiri yang masih dapat diterima lingkungan, c) Mengetahui dan memahami perasaan, pendapat orang lain dan memahami perbedaan, d) Membangkitkan semangat dan motivasi untuk terus terlibat dalam kegiatan-kegiatan, e) Lebih mandiri dan bertindak sesuai dengan keinginan, f) Lebih empati dan sensitif dengan perasaan orang lain, g) Mampu berkomunikasi dengan baik, h) Mengetahui cara belajar yang efektif dan kreatif, i) Memberikan pemahaman terhadap sesuatu tentang pentingnya karakter yang baik, j) Menanamkan nilai-nilai yang positif sehingga terbentuk karakter siswa melalui berbagai contohnyata dalam pengalaman hidup, k) membangun kualitas hidup siswayang berkarakter, l) Menerapkan dan memberi contoh karakter yang baik kepada lingkungan (http://widhoy.multiply.com).Kegiatan Outbound adalah merupakan kegiatan belajar sambil bermainatau sebaliknya. Menurut Vygotsky bermain merupakan peran langsung terhadap perkembanagn kognisi seorang anak dan berperan penting dalamperkembangan social dan emosinya (Mayke, 2001:10)

Menurut Heterington dan Parke, bermain juga berfungsi untuk mempermudah perkembangan kognitif anak. Belajar sambil bermain akan memungkinkan anak meneliti lingkungan, mempelajari segala sesuatu dan memecahkan masalah yang dihadapinya. Bermaian juga meningkatkan perkembangan social anak serta untuk memahami peran orang lain dan menghayati peran yang akan diambilnya setelah ia dewasa kelak(Moeslichatoen, 1999:34).

Menurut David Kolb dalam Aris shoimin, 2014:115 mengemukan 6 siklus proses pembelajaran experiential learning dalam outbound. Pada dasarnya pembelajaran eksperensial sederhana dimulai dengan melakukan (do), refleksikan (refect), kemudian terapkan (apply). Jika dielaborasi lagi, akan terdiri dari lima langkah, yaitu mulai dari proses mengalami (experience), bagi (share), "dirasa-rasa" atau analisis pengalaman tersebut (process), ambil hikmah atau disimpulkan (generalize), dan terapkan (apply). Begituseterusnya kembali ke fase pertama, alami.Suklis 


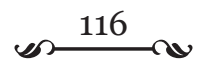

ini sebenarnya never ending. Uwes menjabarkan deskripsi siklus sebagai berikut;

\section{Langkah 1: Experience}

Dalam langkah experience peserta didik akan mengalami suatu hal dan melakukan sesuatu (perform and do it). Dalam langkah ini ada trik service yang mengecoh.Sebagai langkah awal, peserta didik diberikan serve yang mengecoh. Biarkan peserta didik merasakan/mengalami kesulitan dalam menerima serve tersebut. Kemudian ia diminta untuk melakukan hal yang sama, memberikan serve dan teman yang lain menjadi penerima serve. Proses ini dilakukan selama jangka waktu tertentu.

\section{Langkah 2: share (berbagi rasa/pengalaman)}

Setelah semua peserta didik mencoba melakukan trik serve secara bergantian. Maka lankah selanjutnya adalah melakukan proses sharing alias berbagi rasa. Semua peserta didik diminta untuk mengemukakan apa yang dia rasakan baik dari sisi "timing" serve, seperti teknik melempar bola, memukul bola, posisi bola, posisi tangan, posisi berdiri, dan lainlain. Semua hal tersebut diungkapkan secara terbuka, rileks, dengan gaya masing-masing.

\section{Langkah 3: process (analisis pengalaman)}

Tahap ini adalah tidak lanjut dari tahap kedua, yaitu proses menganalisis berbagai hal terkait dnegan apa, mengapa, bagaimana trik serve dilakukan termasuk bagaimana mengatasinya. Hal ini dilakukan dengan diskusi terbuka dan demonstrasi. Bila perlu rekan yang satu dengan yang lain saling mengoreksi dan memberika masukan, termasuk mendemonstrasika cara yang menurutnya lebih baik. Instruktur/guru bisa ikut serta meluruskan cara yang lebih tepat.

\section{Langkah 4: Generalize (menghubungkan pengalaman dengan situasi nyata)}

Langkah selanjutnya adalah menyimpulkan hasil analisis tersebut. Kesimpulan bersama, mungkin telah dihasilkan secara teoritis dari hasil analisis di atas.Namun, belum tentu hal tersebut dapat menyatu atau terintegrasi secara utuh dalam praktik nyata. Oleh karena itu, untuk pembuktian generalisasi dari hasil tersebut perlu dilakukan dengan pengulangan penerapan dalam situasi yang nyata.

\section{Langkah 5: Apply (penerapan terhadap situasi yang serupa}




\section{שת 117}

\section{atau level lebih tinggi)}

Langkah terakhir memiliki kesamaan dengan langkah 4,namun dalam ini level penguasaan ditingkatkan ke hal baru yang lebih tinggi. Hal baru ini akan menjadi bahan menuju langkah experiential learning mulai dari tahap experience-share-process-generalize-apply dan kembali lagi ke siklus awal, begitu seterusnya.

Setelah kegiatan outbound, guru bersama siswa MI dapat membahas kembali apa yang telah dilaksanakan. Metode yang digunakan yaitu metode diskusi, dimana akan diperoleh pendapat yang berbeda dan bervariasi antara siswa yang satu dengan yang lainnya. Guru bertugas menfasilitasi dalam menyisipkan makna (misal pesan moral, sikap dan kerjasama). Misalnya, dalam kegiatan ini yaitu: Udara yang ada di dalam balon memberikan tekanan sehingga ketika dilepaskan balon dapat berlari menuju ke ujung benang yang lain. Udara merupakan benda gas yang mempunyai sifat bentuknya berubah-ubah sesuai dengan tempatnya, udara dapat memberikan tekanan, udara tidak terlihat dan tak dapat dipegang namun bisa dirasakan,dan udara ada di mana-mana/ ada di sekitar. Semakin banyak udara dalam balon maka balon juga akan tampak besar dan tekanannya juga besar. Tekanan besar yang terdapat dalam balon maka larinya semakin cepat artinyadalam kehidupan ini kita harus mengisi kehidupan (seperti balon) dengan menambah wawasan, akhlak yang baik, dan keterampilan-keterampilan, selain itu juga harus memupuk semangat, motivasi dan kemauan yang besar agar akan dapat berlari dengan cepat untuk mencapai cita-cita. Kemudian setelah membahas tentang udara yang ada dalam balon secara ilmiah dan juga dimaknai secara kontekstual dalam kehidupan sehari-hari, siswaselanjutnya diarahkan pada pemanfaatan apa yang sedang dipelajari dengan kehidupan mereka sehingga menjadi orang yang pandai bersyukur atas apa yang sudah diberikan oleh sang pencipta.

Sebagai contoh elemen udara dapat dimanfaatkan untuk berbagai macam seperti Mengisi ban kendaraan, guru dapat menanyakan kepada siswa berapa banyak udara yang di masukkan ke dalam ban kendaraan (sedikit/banyak?) dan dapatkahudara dalamban-ban tersebutmengangkat 50 orang?, Dan berilah tanggapan pada siswa bahwa: meskipun udara yang kita berikan pada ban sedikit, akan tetapi udara memberikan tekanan pada ban sehingga ban menjadi keras dan dapat digunakan kendaraan 


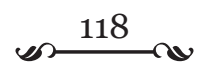

seperti bus untuk mengangkut 50 orang atau lebih(jangan menganggap hal yang sepele, karena hal yang sepele kadang adalah sesuatu yang besar pengaruhnya bagi kehidupan).

Udara juga dimanfaatkan untuk bernafas, tanyakan dari manakahudara yang kita hirup? Bagaimanakah ketika hidungmu tersumbat?bayarkah kita untuk menghirupudara di sekitar kita? Hitunglah berapabanyak tabung gas yang kitaperlukan untuk bernafas hinggahari ini? Siapakah yang menciptakanudara? Dan berikanlah tanggapanpada siswa bahwa: kita dapatbebas bernafas, menghirup udara sebebasbebasnya dimanapunkita berada, diberi nikmat kesehatansehingga dapat bernafas denganbaik Gratis dan jika kita harusbernafas dengan tabung gas makaberapa uang yang akan dikeluarkanhingga kita hidup sampai hari ini.Ini adalah karunia Allah swt yang harus kita syukuri bersama.

Setelah membahas udara sebagai salah satu elemen dari alam ini, kemudian guru dapat memberikan contoh-contoh ayat al-Quran yang dapat menyangkut tentang pemeliharaan alam.Mengingatkan manusia untuk selalu bersyukur dan memelihara alam agar terjaga kelestariannya. Sebagaimana disebutkan dalam alquran bahawa kerusakan dibumi adalaha kibat dari manusia sendiri.Maka keberlangsungan ala mini tergantung dari pengelolaan manusia sendiri.Allah sudah menyediakan alam yang berlimpah dan mempunyai manfaat yang luar biasa dalam memenuhi kebutuhan manusia, namun apabila penggunaan alam yang tidak wajar bisa mengakibatkan kerusakan lingkungan.

\section{Inovasi Pembelajaran di Madrasah}

Berhasil atau tidaknya pendidikan bergantung apa yang diberikandan diajarkanolehguru. Hasil-hasilpengajaran danpembelajaran berbagai bidang disiplin ilmu terbukti selalu kurang memuaskan berbagai pihak yang berkepentingan (stakeholder).Hal tersebut setidak-tidaknya disebabkan oleh tiga hal.Pertama, pendidikan yang kurang sesuai dengan kebutuhan dan fakta yang ada sekarang (need assessment).Kedua, metodologi, strategi dan teknik yang kurang sesuai dengan materi. Ketiga, prasarana yang mendukung proses pembelajaran(shoimin,2014:16).

Diakui atau tidak pada zaman yang modern ini, sebagian besar guru mengajar menggunakan metodologi mengajar tradisional (Shoimin, 2014:17).Cara mengajar tersebut bersifat otoriter dan berpusat pada guru, 


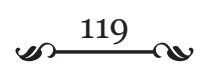

sedangkan siswa hanya dijadikan sebagai objek bukan sebagai subjek. Guru terkesan secara mendominasi dalam proses belajar mengajar. Guru terlihat memberikan ceramah kepada siswa-siswanya sementara siswa hanya mendengarkan. Hal tersebut menyebabkan siswa menjadi jenuh sehingga sulit menerima materi-materi yang diberikan oleh guru.

Oleh sebab itu diperlukan inovasi dan kreasi pembelajaran untuk penguasaan terhadap materi yang dikelola dan ditampilkan secara professional, dari hati tanpa paksaaan, logis dan menyenangkan serta dipadukan dengan pendekatan personal-emosional terhadap peserta didik. Hal ini akan menjadikan proses pembelajaran yang ingin dicapai dapat terwujud. Selain itu, pembelajaran juga harus dibuat bervariasidengan menciptakan suatu metode pembelajaranyang baru atau dengan kata lain inovasi.

Santyasa (2005:5) menyatakanbahwa pembelajaran inovatif adalahpembelajaran yang lebih bersifat studentcentered, artinya pembelajaran yang lebihmemberikan peluang kepada siswauntuk mengkonstruksi pengetahuan secaramandiri (self directed) dan dimediasioleh teman sebaya. Dapat disimpulkanbahwa pembelajaran inovatifadalah pembaharuan pendidikan yangmengaktifkan siswa untuk meningkatkankualitas pendidikan dengan menciptakanpembelajaran student centered.Menurut Marsaja (2007) keunggulanpembelajaran inovatif adalah: (a)kualitas hasil belajar yang dicapai menjadilebih tinggi, (b) lingkup hasil belajarmenjadi lebih komprehensif, (c) pembelajaraninovatif tidak saja menekankanpada hasil belajar kognitif, tetapi jugahasil belajar proses dan sikap. Konsekuensinyatentu akan memerlukanwaktu yang lebih lama karena dilakukanuntuk mencapai banyak hasil belajar.

Pembelajaran inovatif dengan metodeyang berpusat pada siswa (studentcentered learning) juga memiliki keragamanmodel pembelajaran yangmenuntut partisipasi aktif dari siswa.Beberapa metode tersebut di antaranya: a) Berbagi informasi (informationsharing) dengan cara: curah gagasan (brainstorming),kooperatif, kolaboratif,diskusi kelompok (group discussion), diskusi panel (paneldiscussion), simposium, dan seminar, b) Pembelajaran melalui pemecahanmasalah (problem solving basedlearning) dengan cara: studi kasus,tutorial, dan lokakarya, c) Belajar dari pengalaman (experiencebased) dengan cara: simulasi,bermain peran 


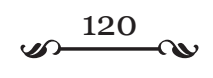

(roleplay), permainan(game), dan kelompoktemu.

Salah satu metode alternatif yangsaat ini sedang digemari dan diyakinilebih berhasil dari kegiatanceramah adalah pendidikan luarruang (outbound education), yangsarat dengan permainan yang menantang,mengandung nilai-nilai pendidikan, dan mendekatkan siswa kepada lingkungan. Dengan pendidikan di luar ruang peserta didik akan berinteraksi dengan lingkunagan yang baru serta dapat memecahkan masalah dengan sendiri maupun dengan berkelompok berdasarkan pengalaman baru yang didapatkannya.

Metode pembelajaran ini dapat meningkatkan minat siswa sesuai dengan kebutuhan siswa.Pembelajaran di luar kelas atau outbound dapat meningkatkan semangat siswa dalam belajar.Mengenali lingkungan yang baru serta melatih siswa untuk dapat berfikir serta mampu mempraktekkan materi pembelajaran secara nyata.

Pendidikan Indonesia saat ini sering lebih menitikberatkan pada bagaimana mengembangkan kecerdasan kognitif sehingga terjebak pada rasionaloriented dan melepaskan orientasi irrasional maupun metafisik, semacam spiritual, dan konsep diri yang dianggap sebagai penghambat. Keadaan yang demikian mengakibatkan pembunuhan karakter yang dimiliki siswa dari sebuah kesatuan dalam dimensi kediriannya. Menurut Abdurrahman (2007:74) proses pembelajaran meliputi keseluruhan unsur baik kognitif, afektif dan psikomotorik. Apabila proses pembelajaran tidak berjalan secara simultan maka akan terjadi split personality (diri yang terpisah) pada setiap siswa.Siswa tidak hanya mampu menangkap pesan lahiriah dari apa yang ia pelajari, namun lebih dari itu siswa juga mampu memproyeksikan pesan dari setiap teori yang ia pelajari. Pendidikan adalah proses interaksi antara siswa dengan dirinya sendiri (konsentris), siswa dan alam sekitar (horizontal) dan interaksi siswa dengan Allah SWT (vertikal), tetapi banyak metode pengajaran sekarang yang memisahmisahkan ketigainteraksi tersebut. Oleh karena itu, guru hendaknya menyadari pentingnya pembelajaran yang bermakna dengan menciptakan keseimbangan antara guru, siswa, dan lingkungan.Hal tersebut dapat diwujudkan dengan memahami dan menerapkan berbagai metode atau model mengajar semisal CTL, CooperativeLearning, Quantum learning Accelerated Learning, dan sebagainya.

Metode belajar inovatif outbound sains dapat menjadi salah 
satusaranayang dapat dimanfaatkan untukmengembangkan pertumbuhan fisik danperkembangan mental siswa seutuhnyasehingga terwujud pembelajaran yangbermakna. Artinya, siswa mampu membangunfisik dan mentalnya dengan belajar sambil bermain karena melalui permainan outbound sains akan terbangun suasana yang lepas, bebas, menyenangkan dan atraktif serta memberi makna dalam belajar siswa.

Dalam pembelajaran outbound sains yang diintegrasiakan dengan PAI akan menghasilkan siswa yang sangat kritis dalam menghubungkan materi dan mendapatkan materi yang bermakna bagi peserta didik. Proses internalisasi nilai-nilai agama Islam yang terkandung dalam mata pelajaran PAI dapat terinntegrasi dalam pelajaran outbounds sains yang sarat dengan nilai-nilai ilahiyah.

\section{Simpulan}

Pembelajaran integratif yang sekarang ini dicanangkan dalam kurikulum 2013 merupakan suatu pola pengembangan metode pembelajaran yang sangat bermakna. Pembelajaran integratif PAI dan Sains dapat menghantarkan siswa berfikir dengan kritis serta mengembangkan pola pikir peserta didik dalam menghubungkan korelasi antar materi yang mereka pelajari. Selanjutnya dalam pembelajaran integratif PAI dan sains, peserta didik dapat menemukan nilai-nilai ketuhanan yang didapatkan dalam pelajaran sains sehingga nilai-nilai Islami dapat terinternalisasi dalam sikap dan kepribadian peserta didik.

Outbound merupakan salah satu metode pembelajaran luar kelas yang dapat mengembangkan kemampuan berpikir, keterampilan sosial, life skill, kemampuan spiritual dan sikap siswa. Prinsip "experiential learning" (belajar melalui pengalaman langsung) pada kegiatan outdoor ini, siswa akanmampu mengembangkan potensi diri, baik secara individu (Personal Development) maupun dalam kelompok (TeamDevelopment). Melalui outbound, siswa dapat secara aktif dilibatkan dalam seluruh kegiatan yang dilakukan yang berinteraksi langsungdengan alam untuk mengenalapa yang mereka lihat serta dapat mengkaitkan materi yang diajarkan dengan praktek yang dilakukan saat melakukan out-bound.

Dalam kegiatan out-bound selain pembelajaran yang berkaitan dengan materi misalkan sains dapat diserap dengan mudah karena secara langsung berinteraksi dengan alam, selain itu kegiatan out-bound siswa dapat di 
arahkan untuk dapat selalau mengingat kepada sang pencipata dengan mengkaitkan materi sains dengan Allah SWT (Sang Pencipta). Sehingga aplikasi dari pembejaran out-bound sains ini siswa mampu mengaplikasikan hasil pembelajaran dengn cara mensyukuri nikmat yang telah diberiakan oleh Allah dan mencintai lingkungan serta menjaga lingkungan dengan baik sebagai tempat hidupnya. 


\section{。 \\ DAFTAR PUSTAKA}

Abdurrahman. 2007. Meaningful Learning Re-Invensi Kebermaknaan Pembelajaran. Yogyakarta: PustakaPelajar

Kadir, Abdul dan Hanun asrofah. 2015. Pembelajaran Tematik. Jakarta: PT RajaGrafindo persada.

Nazarudin. 2007. Managemen pembelajaran.Yogyakarta:Teras.

Rohmad Ms.Pendekatan Integratif Pembelajaran Pendidikan Agama Islam ( PAI ) di Sekolah Pada Abad Informasi. Inovatifjurnal. Volume 1, No 1 Tahun 2015.

Santyasa, I Wayan. 2005. Model Pembelajaran Inovatif dalam Implementasi KBK, Makalah PenataranGuru-Guru SMP, SMA, dan SMKseKabupaten Jembrana Juni-Juli2005. Jembrana: FMIPA IKIPNegeri Singaraja.

Shoimin, Aris. 2014. 68 Model Pembelajaran Innovatif dalam Kurikulum 2013.Jogjakarta: AR-RUZZ MEDIA.

Soetomo. 1993. Dasar-Dasar Interaksi Belajar Mengajar. Surabaya: Usaha Nasional.

Sudjana, Nana. 2004. Dasar-dasar Proses Melajar Mengajar. Bandung: Sinar Baru Algesindo.

Sutikno, Pupuh Fathurrahman dan M.Sobry.2007.Strategi Belajar mengajar: Melalui Penanaman Konsep Umum dan Konsep Islami. Bandung: Refika Aditama.

Tarigan, Djago. 2010. Proses Belajar mengajar Pragmatik. Bandung: Angkasa

Trinova, Zulvia. 2010. Pembelajaran Outbound Sains Yang Bermakna(Meaningful Learning) Dan Inovatif di Madrasah. Ta'dib, Volume 13, NO.2.

Tytler, R. 1996. Constructivism and Conceptual Change View of learning in Science.Majalah pendidikan IPA: Khasanah Pengajaran IPA. Bandung: IMAPIPA 